\title{
The Effects of Mospilan and Aktara Insecticides in the Feed on Egg Production and Meat Quality of Laying Hens
}

\author{
Volodymyr Dukhnytskyi ${ }^{1}$, Galina Bazaka ${ }^{1}$, Vasily Sokolyuk ${ }^{2 *}$, Petro Boiko ${ }^{3}$ and Irina Ligomina $^{2}$ \\ ${ }^{I}$ National University of Life and Environmental Sciences of Ukraine, Heroyiv Oborony st., 15, Kyiv - 03041, Ukraine \\ ${ }^{2}$ Zhytomyr National Agroecological University, Zhytomyr, Staryi Blvd., 7, Zhytomyr, 10008, Ukraine \\ ${ }^{3}$ Lesya Ukrainka Eastern European National University, Volya Avenue, 13, Lutsk, 43025, Ukraine \\ *Corresponding author's Email: vmsokoluk@ gmail.com; ORCID: 0000-0003-2311-1910
}

Received: 30 Oct. 2019

Accepted: 08 Dec. 2019

\begin{abstract}
The current study was aimed to investigate the effects of feeding Mospilan and Actara insecticides on egg production performance and meat quality of laying hens. Experimental research was conducted in the laboratory of the Department of Pharmacology and Toxicology of the National University of Life and Environmental Sciences of Ukraine in 2015. The experiments were performed on five groups each consisting of seven chickens. The age of the chickens at the beginning of the experiment was 150 days. The birds were fed the granulated compound feed. In M1 and M2 groups, Mospilan at doses of $65 \mathrm{mg} / \mathrm{kg}$ and $32.5 \mathrm{mg} / \mathrm{kg}$ of body weight were added to the feed, respectively. In A1 and A2 groups, Actara at doses of $360 \mathrm{mg} / \mathrm{kg}$ and $180 \mathrm{mg} / \mathrm{kg}$ of body weight were added to the feed, respectively. Chickens of the control group were fed without the addition of insecticides to the feed. The feeding period lasted 30 days and finally, egg production performance, meat quality, and gross pathological changes were evaluated. Egg production rate in M1 and M2 groups in comparison to the control group decreased by 78.4 and $29.7 \%$, respectively. Egg production rate in A1 and A2 groups reduced by $89.2 \%$ and $48.7 \%$ compared to the control group, respectively. Chickens in groups of receiving insecticides had pale skin and enlarged heart, also showed spot hemorrhages in mucous membranes of the glandular stomach and intestine, color heterogeneity of the lungs, and the liver was dark cherry in color with hemorrhage. In addition, the relative weights of internal organs decreased by 23$36 \%$ in experimental groups. In the experimental groups, the $\mathrm{pH}$ of meat decreased at day 4 post-slaughter, and the meat broth with the addition of $5 \%$ copper sulfate solution was slightly cloudy with flakes. The meat of birds from the experimental groups was low toxic. Extracts from chicken meat of the experimental groups caused pathological changes, inhibition of movements and death of 13-16\% of Tetrahymena pyriformis infusoria. This study demonstrated that the presence of Mospilan and Aktara in feed reduced the egg production rate, caused chronic poisoning, changed biochemical processes in chicken meat and increased its toxicity.
\end{abstract}

Key words: Chicken meat quality, Egg productivity, Insecticides Mospilan and Actara, Laying hens, Neonicotinoids.

\section{INTRODUCTION}

The use of chemical plant protection products, including insecticides, is an integral component of modern agricultural production. Until the year 2000, organophosphorus, pyrethroids and carbamates comprised $80 \%$ of the global production of insecticides. Nowadays, new generation compounds such as neonicotinoids, are widely used and already registered in almost 100 countries (Kovalenko et al., 2010). In Ukraine, more than 150 insecticides on the basis of five neonicotinoid active substances, namely imidacloprid, thiacloprid, thiamethoxam, acetamiprid, and clothianidin are approved. Today, the most widely used neonicotinoids are thiamethoxam and acetamiprid (Kovalenko et al., 2010; Sekun, 2012; Govorov et al., 2013) and the commercial insecticides of Actara and Mospilan have been developed upon their basis, respectively. In Ukraine, these drugs according to "Hygienic classification of pesticides by degree of danger" (MHU, 1998) belong to Class IV toxicity (low toxic substances; $\mathrm{LD}_{50}=501-5000 \mathrm{mg} / \mathrm{kg}$ of body weight in mice) and have high efficacy, low accumulation in mammalian tissues, and moderate persistence in environment (Kovalenko et al., 2010; Sekun, 2012; Govorov et al., 2013; Lin et al., 2019).

The intensive use of pesticides in crop production leads to the accumulation in animal and poultry feed 
(Tomizawa et al., 2009). Moreover, farmers may apply pesticides in violation of technical guidelines (using excessive concentrations, increasing the frequency of application, ignoring the required preharvest intervals), which contributes to the accumulation of pesticide residues in the environment (Bartlett et al., 2019) and animal tissues, which negatively affect human health (Craddock et al., 2019). In this regard, cases of neonicotinoids poisoning in animals and birds have increased in recent years (See, 2009; Seceroglu et al., 2012; Lopez-Antia, 2015). In addition, neonicotinoids have been detected in foods of animal origin such as milk, meat and eggs (Seccia et al., 2008; Selvi et al., 2012; Yang et al., 2012; Lachat et al., 2018).

There are almost no data on toxicity and long-term impacts of accumulation of acetamiprid and thiamethoxam in the organs and tissues of animals and birds. Therefore, the investigations are needed to address the potential risks of neonicotinoids to facilitate their safe use in crop production. The aim of the present study was to evaluate the effects of the long-term intake of Mospilan and Actara insecticides on egg production, quality, and toxicity of chicken meat as well as gross pathological aspects in internal organs.

\section{MATERIALS AND METHODS}

\section{Ethical approval}

All animal experiments were in accordance with the Law of Ukraine «On the Protection of Animals from Brutal Treatment» and the recommendations of the Directive 2010/63/EU of the European Parliament and of the Council of 22 September 2010 on the protection of animals used for scientific purposes.

\section{Animals and study design}

This study was conducted in the laboratory of the Department of Pharmacology and Toxicology of the National University of Life and Environmental Sciences of Ukraine in 2015. The experiments were performed on 35 laying hens, Belarus- 9 cross, with a mean body weight of $1049 \pm 50 \mathrm{~g}$. The age of the chickens at the beginning of the experiment was 150 days. The birds were kept in the vivarium in accordance with the Sanitary Rules on the Organization, Equipment, and Maintenance of Experimental-Biological Clinics (Vivarium) in Ukraine. The hens were placed in five cages $\left(1 \times 1 \mathrm{~m}^{2}\right)$ with seven chickens in each cage. Each cage was equipped with a 40 $\mathrm{W}$ bulb. The chickens were fed the granulated compound commercial feed (Kalinka-7021, Trouw Nutrition
Ukraine). The compound feed consisted of corn (30\%), wheat $(20 \%)$, soybean meal $(20 \%)$, sunflower meal $(15.5 \%)$, soybean oil (1.5\%), enzymes, limestone, kitchen salt, monocalcium phosphate, vitamin, and mineral premix. The nutrient composition of the feed is presented in table 1 .

Table 1. Nutrient composition of feed for laying hens

\begin{tabular}{lc}
\hline Nutrient & Value \\
\hline Crude fiber (\%) & 4.2 \\
Crude fat (\%) & 3.6 \\
Calcium (\%) & 3.8 \\
Phosphorus (\%) & 0.59 \\
Energy, Kcal $/ 100 \mathrm{~g}$ & 305 \\
Total protein $(\%)$ & 14 \\
\hline
\end{tabular}

Feed was given on average $100 \mathrm{~g} /$ chicken/day and water provided ad libitum. Before the beginning of the experiment, the birds were kept for 15 days as an adaptation period. The experiment included five groups with seven birds in each group. Chickens in the control group were fed the basal diet without additives. The birds in M1 and M2 groups were fed the basal diet containing the Mospilan (Nippon Soda Co., Ltd, Japan) at a dose of 65 and $32.5 \mathrm{mg} / \mathrm{kg}$ of average body weight, respectively (equal to $1 / 10$ and $1 / 20 \mathrm{LD}_{50}$ in mice, respectively). The chickens in A1 and A2 groups were fed the basal diet containing the Actara (Kwizda Agro $\mathrm{GmbH}$, Austria) at a dose of 360 and $180 \mathrm{mg} / \mathrm{kg}$ of average body weight, respectively (equal to $1 / 10$ and $1 / 20 \mathrm{LD}_{50}$ in mice, respectively).

The experiment period lasted 30 days. The birds were monitored throughout the experiment. Consideration was given to appearance, reaction to external stimuli, the intensity and nature of the locomotor activity, the condition of the feather cover and mucous membranes. Also, the birds were observed for changes in body position, behavior, feed and water intake. The egg production of laying hens was determined by counting the number of eggs laid per 10 days in each group. At the end of the experiment, chickens were slaughtered to examine pathological changes and to evaluate the meat quality.

\section{Laboratory studies}

Pre-slaughter inspection and post-mortem examinations were carried out in accordance with Ukraine "Rules of veterinary inspection of slaughtered animals and veterinary examination of meat and meat products" (MAPU, 2002, Yakubchak, 2012). Pathological changes were evaluated by gross examination of the internal 
organs. In addition, relative weights of internal organs (liver, spleen, lungs, heart, muscular and glandular stomach) calculated by the following formula:

$$
\mathrm{RW}=\frac{\text { organ weight }(\mathrm{g})}{\text { body weight }(\mathrm{g})} \times 100 \%
$$

Meat quality was evaluated according to (URTCSCQ, 2015). Muscle tissue samples were collected from each slaughtered bird. The freshness of the meat was determined 24 hours and 4 days post-slaughter. To assess the meat freshness by the reaction of meat broth with a $5 \%$ solution of copper sulfate, $20 \mathrm{~g}$ of shredded meat and 60 $\mathrm{ml}$ of distilled water placed in a conical flask. The flask was placed in a boiling water bath for 10 minutes and after that, the broth was filtered. Then $2 \mathrm{ml}$ filtered broth was poured into a test tube and 3 drops of $5 \%$ copper sulfate solution was added, the test tube was shaken and left for 5 minutes, then results from reaction read.

In addition, the freshness of meat was evaluated by reaction with peroxidase. For this, $2 \mathrm{ml}$ of water extract of meat was poured into a test tube and 5 drops of $0.2 \%$ alcoholic solution of benzidine and 2 drops of $1 \%$ hydrogen peroxide solution added.

The $\mathrm{pH}$ of meat determined by the potentiometric method of URTCSCQ (2015) in aqueous extract

The toxicity of the chicken meat was determined using the Tetrahymena pyriformis infusorium as a test organism (Lemesh et all 1997). Briefly, $50 \mathrm{mg}$ of muscle tissue from each meat sample and $8 \mathrm{ml}$ of $0.56 \%$ solution of pharmacy sea salt were poured into a porcelain mortar, then mixed to make a homogeneous mass. Next, $2 \mathrm{ml}$ of homogeneous mass was put in a glass vial and one drop of a three-day culture of Tetrahymena pyriformis infusorium strain WH14, grown on peptone medium, added. The vials were closed with corks with holes, shacked and placed in a laboratory container and incubated at $25{ }^{\circ} \mathrm{C}$ for 3 days. After incubation, from each vial, one drop of infusoria culture was placed on a slide and examined under a microscope with low magnification. Toxicity was assessed by the presence of dead infusoria, inhibition of growth as well as changes in their shape and movement.

\section{Statistical analysis}

The results were statistically processed by using the Microsoft Excel Data Analysis ToolPak. The differences between the values were evaluated using the Student's ttest. A p-value $\leq 0.05$ was considered statistically significant.

\section{RESULTS AND DISCUSSION}

During the experiment, chickens in the control and experimental groups moved actively and responded appropriately to external stimuli. Body temperature was within the physiological range $\left(41-42{ }^{\circ} \mathrm{C}\right)$. Visible clinical signs of poisoning and death were not found.

\section{Egg production performance}

Egg production in M1 group in comparison to control group decreased by $9.7,51.4$ and $78.4 \%$ during the first, second and third 10 days of study, respectively ( $\mathrm{p} \leq$ 0.05 ), while reduction in egg production in M2 group was $2,8.6$ and $29.7 \%$ in aforementioned intervals, respectively $(\mathrm{p} \leq 0.05)$ (Figure 1). Egg production in A1 group recorded $6.5,68.6$ and $89.2 \%$ reduction during the first, second and third 10 days of the experimental period, which was significantly different compared to the control group ( $\mathrm{p} \leq 0.05$ ). The egg production rate of A2 group was similar to that of the control group during the first 20 days of study. However, during 21 to 30 days of study, the production rate in $\mathrm{A} 2$ group in comparison to the control group decreased by $48.7 \%(p \leq 0.05)$ (Figure 1$)$.

The decrease in egg production indicates metabolic disorders, the development of profound changes in internal organs and the body as a whole (Bazaka et al., 2017). In this study, the reducing effect of Mospilan on the egg production of chickens was less than the Actara effect, although the toxicity of Mospilan was significantly higher for mice in the laboratory experiments (Bazaka et al., 2017). It is known that chronic pesticide poisoning disrupts the barrier function of the intestinal mucosa, thereby providing conditions for the spread of intestinal microflora in the body and the occurrence of secondary infections (See, 2009; Seceroglu et al., 2012; Lopez-Antia, 2015).

According to Millot et al. (2017) large-scale use of neonicotinoid insecticides has raised growing concerns about their potential adverse effects on farmland birds. They reviewed the mortality incidents partridges and pigeons, for which toxicological analyses detected imidacloprid residues. Mortality was due to poisoning by imidacloprid-treated seeds.

According to Van Lexmond et al. (2015) consumption of small numbers of dressed seeds offers a potential route for direct mortality in granivorous mammals and birds, for such birds need to eat only a few spilt seeds to receive a lethal dose. Lower doses lead to a range of symptoms including impaired immune function, reduced fecundity and lethargy. 


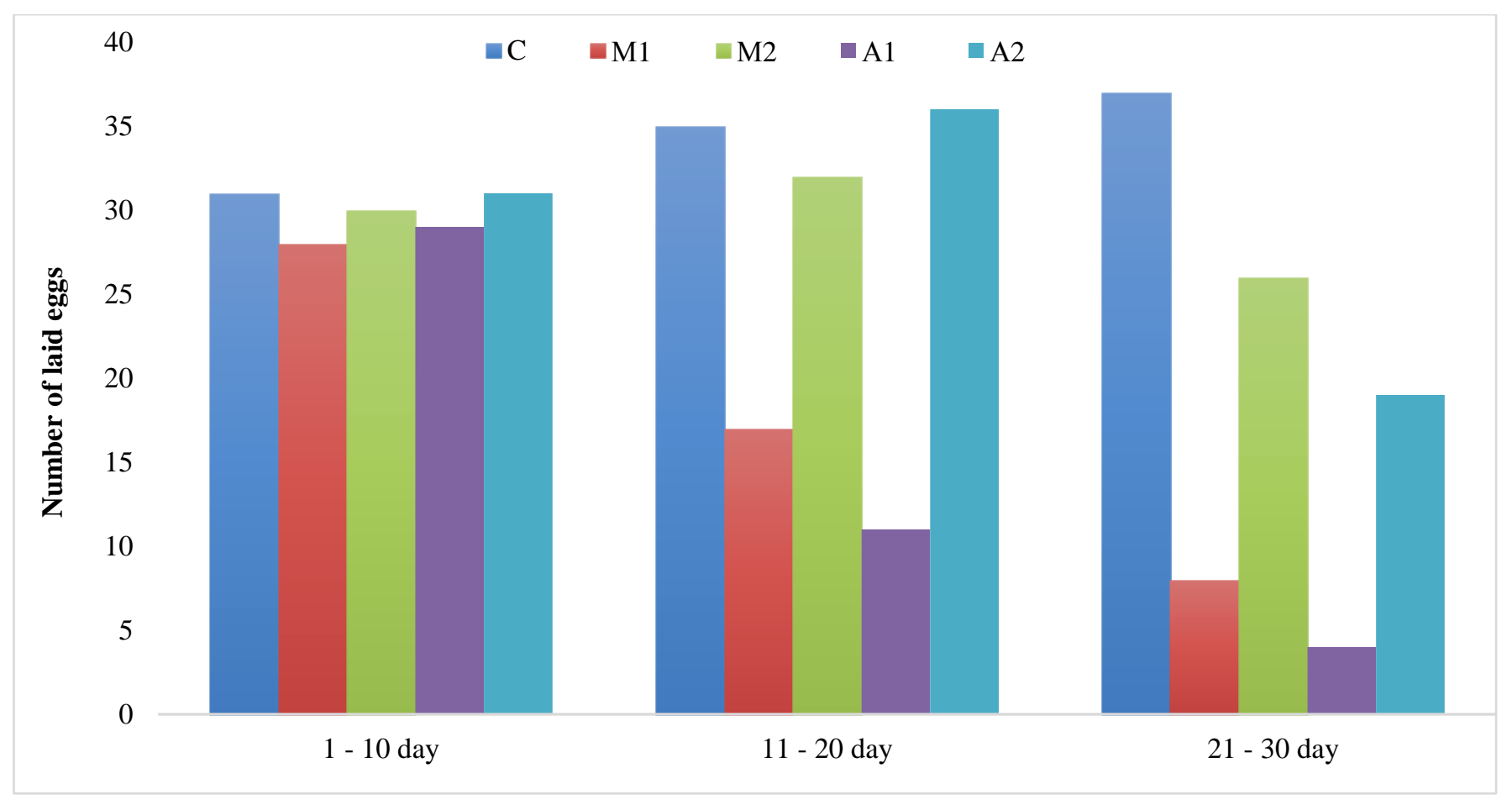

Figure 1. Egg production performance of laying hens in presence of Mospilan and Aktara insecticides in the feed. M1 and M2 groups were fed the basal diet containing the Mospilan at a dose of 65 and $32.5 \mathrm{mg} / \mathrm{kg}$ of body weight, respectively. A1 and A2 groups were fed the basal diet containing the Actara at a dose of 360 and $180 \mathrm{mg} / \mathrm{kg}$ of body weight, respectively. C: Control group.

\section{Meat quality}

Inspection of carcasses of birds slaughtered in experimental groups (M1, M2, A1, and A2) revealed that the surfaces of carcasses were pale and had a distinct smell, which was not typical for fresh poultry. Other organoleptic parameters corresponded to fresh meat.On day 4 post-slaughter, $\mathrm{pH}$ values of meat in $\mathrm{M} 2$ and $\mathrm{A} 1$ groups were less than that in M1, A2 and control groups; whereas the $\mathrm{pH}$ of chicken meat in experimental groups at 1 day post-slaughter was slightly different from that of the control group (Figure 2).

Assessment of the meat quality by the reaction of broth with 5\% copper sulfate solution indicated that the meat broth in samples obtained from the control group was clear. While the broth samples from the experimental groups were cloudy with flakes appearance, indicating the occurrence of biochemical changes in the meat and doubtful freshness of chicken meat.

Determination of peroxidase activity in meat samples from control and experimental groups after 1 and 4 days storage at $2-4{ }^{\circ} \mathrm{C}$ showed that aqueous extracts were bluegreen, which turned brown. This indicated a high activity of peroxidase.
Thus, the results of the veterinary-sanitary evaluation of laying carcasses indicated some disturbances of biochemical processes in tissues affected by Mospilan and Actara that may have negative effects on the quality and safety of meat over long periods of storage.

The evaluation of toxicity using the Tetrahymena pyriformis infusorium revealed that chicken meat of all experimental groups was slightly toxic. The meat extracts of chickens in the M1 group resulted in the death of $18 \%$ of Tetrahymena pyriformis, inhibition of movements in $76 \%$ infusoria and morphological changes in $2.0 \%$ infusoria. Extracts of poultry meat obtained from the M2 group resulted in the death of $16.0 \%$ of infusoria, inhibition of movements in $79.0 \%$ infusoria and morphological changes in $1 \%$ cases.

Chicken meat extracts of the A1 group led to the death of $15.0 \%$ of infusoria, also cells with inhibited movements and morphological changes were $75 \%$ and $4 \%$, respectively. The results of the toxicological evaluation of the chicken meat in the $\mathrm{A} 2$ group revealed that $13 \%$ of infusions were dead, $75 \%$ and $4.0 \%$ were cells with inhibited movements and morphological changes, respectively. 


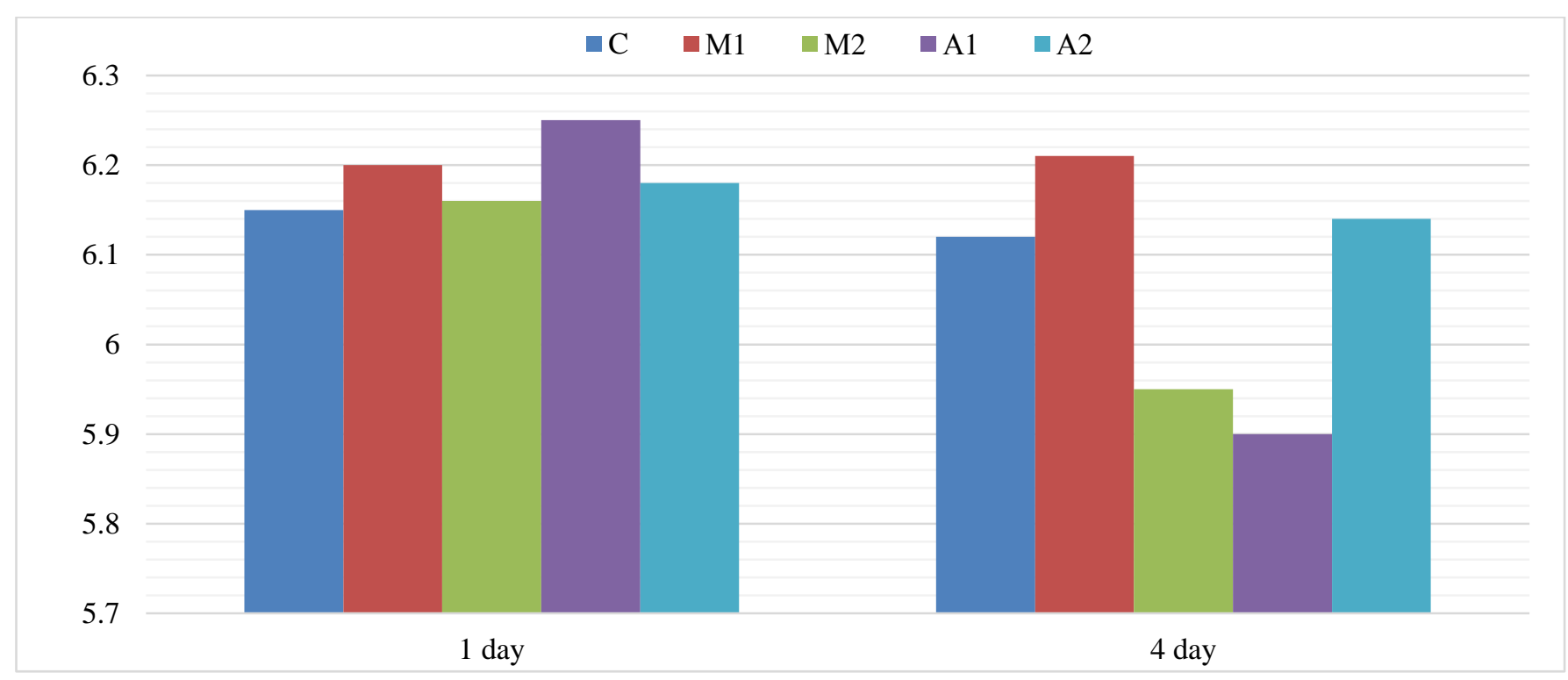

Figure 2. The $\mathrm{pH}$ of meat of laying hens in presence of Mospilan and Aktara insecticides in the feed. M1 and M2 groups were fed the basal diet containing the Mospilan at a dose of 65 and $32.5 \mathrm{mg} / \mathrm{kg}$ of body weight, respectively. A1 and A2 groups were fed the basal diet containing the Actara at a dose of 360 and $180 \mathrm{mg} / \mathrm{kg}$ of body weight, respectively. C: Control group

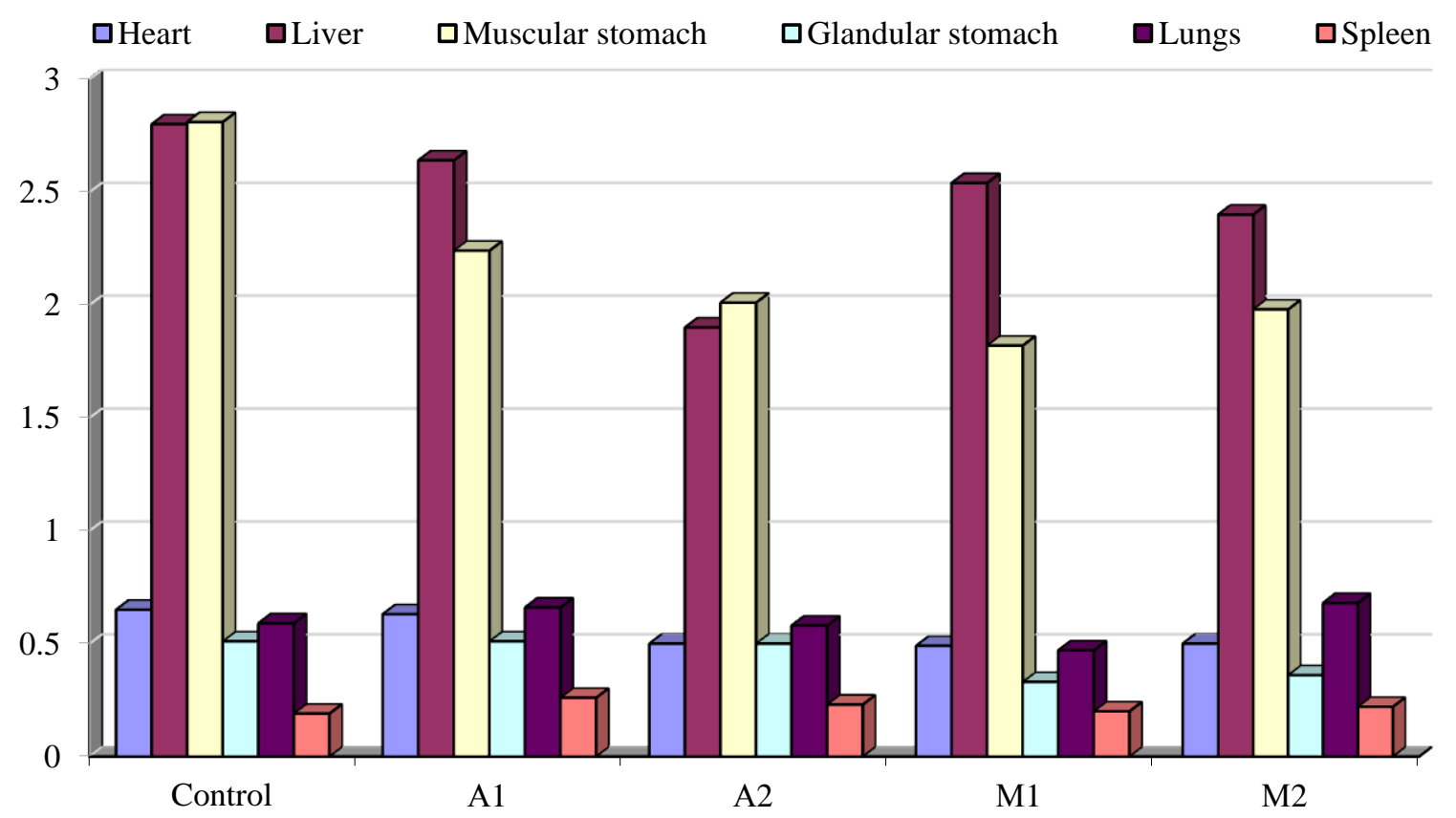

Figure 3. The relative weights of the internal organs of laying hens in presence of Mospilan and Aktara insecticides in the feed. M1 and M2 groups were fed the basal diet containing the Mospilan at a dose of 65 and $32.5 \mathrm{mg} / \mathrm{kg}$ of body weight, respectively. A1 and A2 groups were fed the basal diet containing the Actara at a dose of 360 and $180 \mathrm{mg} / \mathrm{kg}$ of body weight, respectively. C: Control group.

The relative weights of the internal organs are shown in figure 3. The obtained results in M1 group indicated a significant decrease in the relative weight of heart by $25 \%$, liver by $9 \%$, lungs by $20 \%$, and glandular stomach by $35 \%$ compared to the control group ( $\mathrm{p} \leq 0.05)$. In A1 group in comparison to the control, a decrease in the relative weight of liver, lungs, and muscular stomach, as well as an increase in the relative weight of spleen by $37 \%$ was observed $(p \leq 0.05)$. In $A 2$ group, the relative weight of heart significantly decreased by $23.0 \%$, and liver by $32.0 \%$, however, the relative spleen weight was $21 \%$ higher than that in the control group $(\mathrm{p} \leq 0.05)$. 
Gross examination of the internal organs of laying hens in the experimental groups revealed heterogeneity in color of lungs, enlargement of the heart, hemorrhage in the liver, spot hemorrhages on the mucous membrane of the glandular stomach and intestines. Also, some chickens showed swelling of the small intestine. The pathological changes in the body indicated chronic poisoning. Reduction of egg production, deterioration and pathomorphological changes in the body of birds demonstrated the negative effect of insecticides Mospilan and Actara, even at doses of $1 / 10$ and $1 / 20 \mathrm{LD}_{50}$ for mice.

\section{CONCLUSION}

The contamination of feed of laying hens with Mospilan and Actara in subtoxic doses caused chronic poisoning, which led to decreased egg production and meat quality, reduced the weight of the liver, kidneys, lungs, stomach as well as hemorrhages in the liver and mucous membrane of the glandular stomach and intestines.

\section{DECLARATIONS}

\section{Author's contribution}

Galina Bazaka and Volodymyr Dukhnytskyi conducted the research, collected data and performed the statistical analysis. Vasily Sokolyuk, Petro Boiko and Irina Ligomina wrote the manuscript. All authors read and approved the final manuscript.

\section{Competing interests}

The authors have declared that no competing interest exists.

\section{REFERENCES}

Bartlett AJ, Hedges AM, Intini KD, Brown LR, Maisonneuve FJ, Robinson SA, Gillis PL and de Solla SR (2019). Acute and chronic toxicity of neonicotinoid and butenolide insecticides to the fresh water amphipod, Hyalella Azteca. Ecotoxicology and Environmental Safety, 175: 215-223.

DOI: https://doi.org/10.1016/j.ecoenv.2019.03.038.

Bazaka GYa., Dukhnitskyi VB and Ishchenko VD (2017). Comparative study of Mospilan and Akhtara chronic toxicity for white mice. Scientific Bulletin of the National University of Life and Environmental Sciences of Ukraine. Series Veterinary medicine, quality and safety of animal products, 265: 8-17. Available at: http://journals.nubip.edu.ua/index.php/Veterenarna/articl e/view/10606.

Craddock HA, Huang D, Turner PC, Quirós-Alcalá L and PayneSturges DC (2019).Trends in neonicotinoid pesticide residues in food and water in the United States, 19992015. Environmental Health, 18(1): 7. DOI: https://doi.org/10.1186/S12940-018-0441-7.

Govorov DN, Jivyih AV and Chetvertin SN (2013). Primenenie pestitsidov. Zaschita i karantin rasteniy, 4: 6-8. Available at: https://cyberleninka.ru/article/n/15015060

Kovalenko VG, Tyurina NM and Kazadaeva SV (2010). Pesticides in the system of integrated control over the development and spread of pests and diseases of crops. Agricultural Chemistry, 4: 43-52. Available at: https://naukabooks.ru/zhurnali/katalog/agrohimija/

Lachat L and Glauser G (2018). Development and validation of an Ultra-Sensitive UHPLC-MS/MS method for neonicotinoid analysis in milk. Journal of Agriculture and Food Chemistry, 66 (32): 8639-8646. DOI: https://doi.org/10.1021/acs.jafc.8b03005.

Lemesh VM, Pakhomov PI and Yanchenko AE (1997). Methodical instructions for toxico-biological assessment meat, meat products and milk by the use Tetrahymena pyriformis infusoria (express method). Vitebsk, p. 13.

Lin S, Han Y, Jiangyuan C, Luo Y, Xu W, Luo H and Pang G (2019). Revealing the biodiversity and the response of pathogen to a combined use of procymidone and thiamethoxam in tomatoes. Food Chemistry, 30 (284): 73-79. DOI: https://doi.org/10.1016/j.foodchem.2019.01.094.

Lopez-Antia A (2015). Imidacloprid-treated seed ingestion has lethal effect on adult partridges and reduces both breeding investment and offspring immunity. Environmental Research, 136: 97-107. DOI: https://doi.org/10.1016/j.envres.2014.10.023

Millot F, Decors A and Mastain O (2017). Field evidence of bird poisonings by imidacloprid-treated seeds: a review of incidents reported by the French SAGIR network from 1995 to 2014. Environmental Science and Pollution Research, 24: 54-69. DOI: https://doi.org/10.1007/s11356-016-8272-y

Ministry of Agrarian Policy of Ukraine (MAPU) (2002). Rules of pre-slaughter veterinary inspection of animals and veterinary examination of meat and meat products. Ministry of Agrarian Policy of Ukraine. Order, Rule on June 7, 2002, No 28. Available at: https://zakon.rada.gov.ua/laws/show/en/z0524-02

MHU (1998). Ministry of Health of Ukraine. State sanitary rules and hygiene norms "Hygienic classification of pesticides by degree of danger". Available at: http://mozdocs.kiev.ua/view.php?id=4164

See AM (2009). Toxicity in three dogs from accidental oral administration of a topical endectocide containing moxidectin and imidacloprid. Australian Veterinary $\begin{array}{llll}\text { Journal, } & 87 & (8): & 334-337 .\end{array}$ https://doi.org/10.1111/j.1751-0813.2009.00448.x.

Selvi C, Paramasivam M, Rajathi DS and Chandrasekaran S (2012). Multiresidue analysis of organochlorine pesticides in milk, egg and meat by GC-ECD and confirmation by GC-MS. Bulletin of Environmental Contamination and Toxicology, 89 (5): 1051-1056. DOI: https://doi.org/10.1007/s00128-012-0789-2.

Sekun MP (2012). Neonikotynoidy v ahrarnomu vyrobnytstvi. Zakhyst i karantyn Roslyn, 58: 180-191. Available at: 
https://cyberleninka.ru/article/n/15015060

Seceroglu V, Seceroglu ZA and Demirhan ES (2012). Effects of commercial formulations deltamethrin and/or thiacloprid on thyroid hormone levels in rat serum. Toxicology and Health, 60: 220-225. DOI: https://doi.org/10.1177/0748233712448114.

Seccia S, Fidente P, Montesano D and Morrica P (2008). Determination of neonicotinoid insecticides residues in bovine milk samples by solid-phase extraction clean-up and liquid chromatography with diode-array detection. Journal of Chromatography A, 1214 (1-2): 115-220. DOI: https://doi.org/10.1016/j.chroma.2008.10.088.

Tomizawa M and Casida JE (2009). Molecular recognition of neonicotinoid insecticides: the determinants of life or death. Accounts of Chemical Research, 42 (2): 260-269. DOI: https://doi.org/10.1021/ar800131p.

Ukrainian Research and Training Center of Standardization, Certification and Quality (URTCSCQ) (2015). Poultry meat. National Standard of Ukraine, Methods for chemical analysis of freshness, DSTU 8253: 2015. Available at: http://csm.kiev.ua/index.php

Van Lexmond M, Bonmatin J, Goulson D and Noome D (2015). Worldwide integrated assessment on systemic pesticides. Environmental Science and Pollution Research, 1: 1-4. DOI: https://doi.org/10.1007/s11356-014-3220-1

Yakubchak OM (2012). Methodical instructions on veterinary and sanitary examination with the basics of technology and standardization of meat and meat products. Kyiv, p.168.

Yang L, Li H, Zeng F, Liu Y, Li R, Chen H, Zhao Y, Miao H and $\mathrm{Wu} Y$ (2012). Determination of 49 organophosphorus pesticide residues and their metabolites in fish, egg, and milk by dual gas chromatography-dual pulse flame photometric detection with gel permeation chromatography cleanup. Journal of Agriculture and Food Chemistry, 60 (8):1906-1913. DOI: https://doi.org/10.1021/jf2043828. 